\title{
Late Oligocene-Early Miocene shortening in the Thrace Basin, northern Aegean
}

\author{
Ümitcan Erbil ${ }^{1,4}$ (D) Aral I. Okay ${ }^{1,2}$ (1) Aynur Hakyemez ${ }^{3}$ (1)
}

Received: 10 November 2020 / Accepted: 5 May 2021 / Published online: 15 May 2021

(c) The Author(s) 2021, corrected publication 2021

\begin{abstract}
Late Cenozoic was a period of large-scale extension in the Aegean. The extension is mainly recorded in the metamorphic core complexes with little data from the sedimentary sequences. The exception is the Thrace Basin in the northern Aegean, which has a continuous record of Middle Eocene to Oligocene marine sedimentation. In the Thrace Basin, the Late Oligocene-Early Miocene was characterized by north-northwest $\left(\mathrm{N} 25^{\circ} \mathrm{W}\right)$ shortening leading to the termination of sedimentation and formation of large-scale folds. We studied the stratigraphy and structure of one of these folds, the Korudağ anticline. The Korudağ anticline has formed in the uppermost Eocene-Lower Oligocene siliciclastic turbidites with Early Oligocene (31.6 Ma zircon U-Pb age) acidic tuff beds. The turbidites are underlain by a thin sequence of Upper Eocene pelagic limestone. The Korudağ anticline is an east-northeast $\left(\mathrm{N} 65^{\circ} \mathrm{E}\right)$ trending fault-propagation fold, $9 \mathrm{~km}$ wide and $22 \mathrm{~km}$ long and with a subhorizontal fold axis. It is asymmetric with shallowly-dipping northern and steeply-dipping southern limbs. Its geometry indicates about $1 \mathrm{~km}$ of shortening in a $25^{\circ} \mathrm{W}$ direction. The folded strata are unconformably overlain by Middle Miocene continental sandstones, which constrain the age of folding. The Korudağ anticline and other large folds in the Thrace Basin predate the inception of the North Anatolian Fault (NAF) by at least 12 myr. The Late Oligocene-Early Miocene (28-17 Ma) shortening in the Thrace Basin and elsewhere in the Balkans forms an interlude between two extensional periods, and is probably linked to changes in the subduction dynamics along the Hellenic trench.
\end{abstract}

Keywords Thrace Basin $\cdot$ Shortening $\cdot$ Oligocene $\cdot$ Miocene $\cdot$ Aegean

Ümitcan Erbil

erbilumt@gmail.com; umit.erbil@fu-berlin.de

Aral I. Okay

okay@itu.edu.tr

Aynur Hakyemez

aynurhakyemez@yahoo.com

1 Eurasia Institute of Earth Sciences, Istanbul Technical University, 34469 Maslak, Turkey

2 Department of Geology, Faculty of Mines, Istanbul Technical University, 34469 Maslak, Turkey

3 Department of Geological Research, General Directorate of Mineral Research and Exploration (MTA), 06800 Ankara, Turkey

4 Present Address: Institut für Geologische Wissenschaften, Freie Universität Berlin, Malteserstrasse 74-100, 12249 Berlin, Germany

\section{Introduction}

The Aegean has been a region of major crustal extension in the Cenozoic related to the southward migration of the Hellenic subduction zone (Le Pichon and Angelier 1979; Jolivet et al. 2013). The north-south extension is well documented in the metamorphic core complexes in the Cycladic islands, Rhodopes and in the Western Anatolia (Fig. 1; Hetzel et al. 1995; Okay and Satir 2000; Cavazza et al. 2009; Jolivet and Brun 2010; Brun and Sokoutis 2018). Seismicity and the GPS measurements indicate that the Aegean region is extending at present in NNE-SSW direction at a rate of 2-3 cm/year (Reilinger et al. 2010). A significant question is whether the extension was continuous since the Late Eocene, or was it episodic with phases of no extension and/or shortening (e.g., Burchfiel et al. 2008). A suitable region to answer this question is the Thrace Basin in northern Aegean, which is a major sedimentary basin with sedimentation ranging from Middle-Late Eocene to Late Oligocene (Figs. 2, 3; Turgut et al. 1991; Siyako and Huvaz 


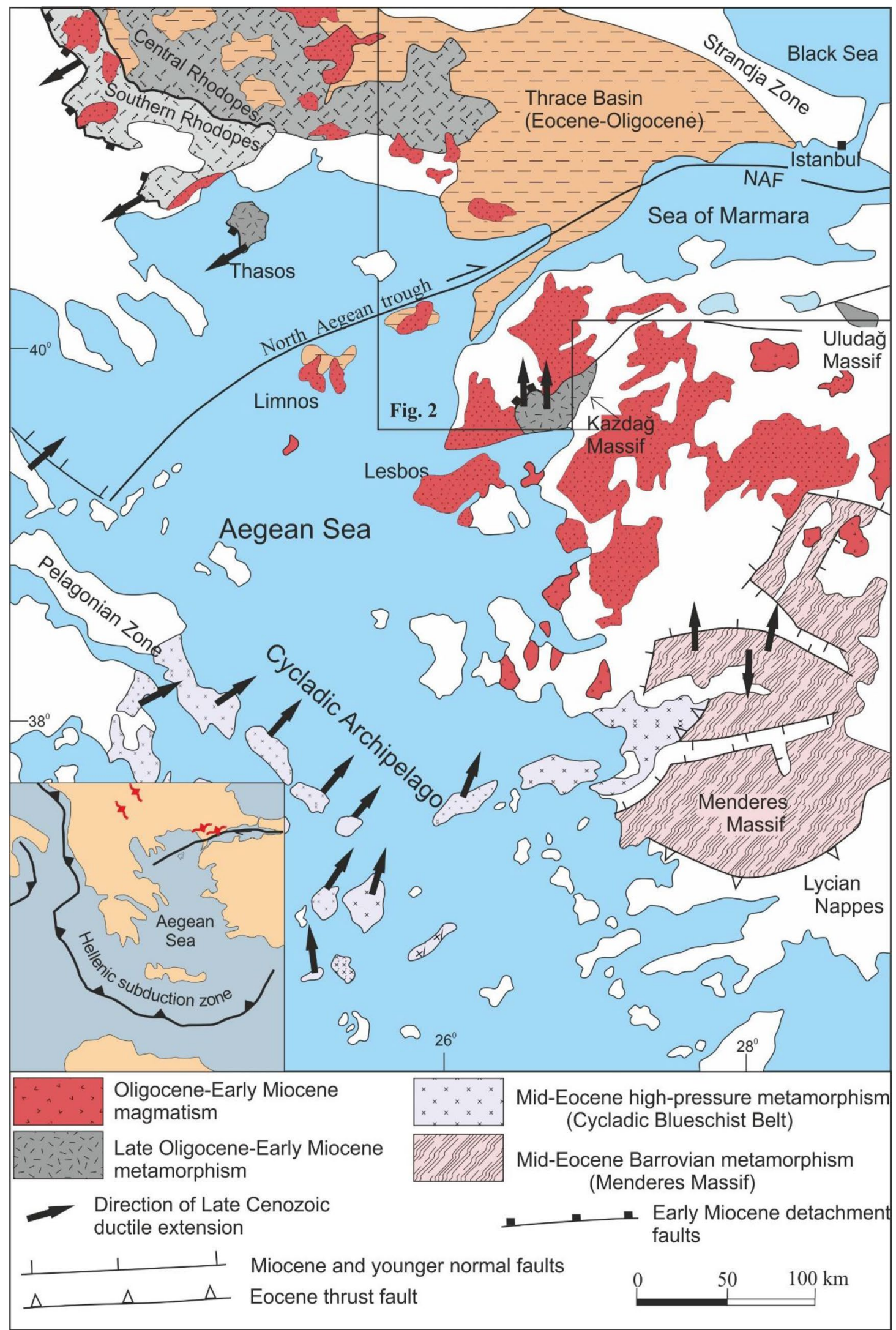

Fig. 1 Tectonic map of the Aegean region showing the setting of the Thrace Basin and distribution of the Late Oligocene-Early Miocene magmatic and metamorphic areas. The inset shows the present tectonics of the Aegean; the red lines mark Late Oligocene-Early Miocene folds 


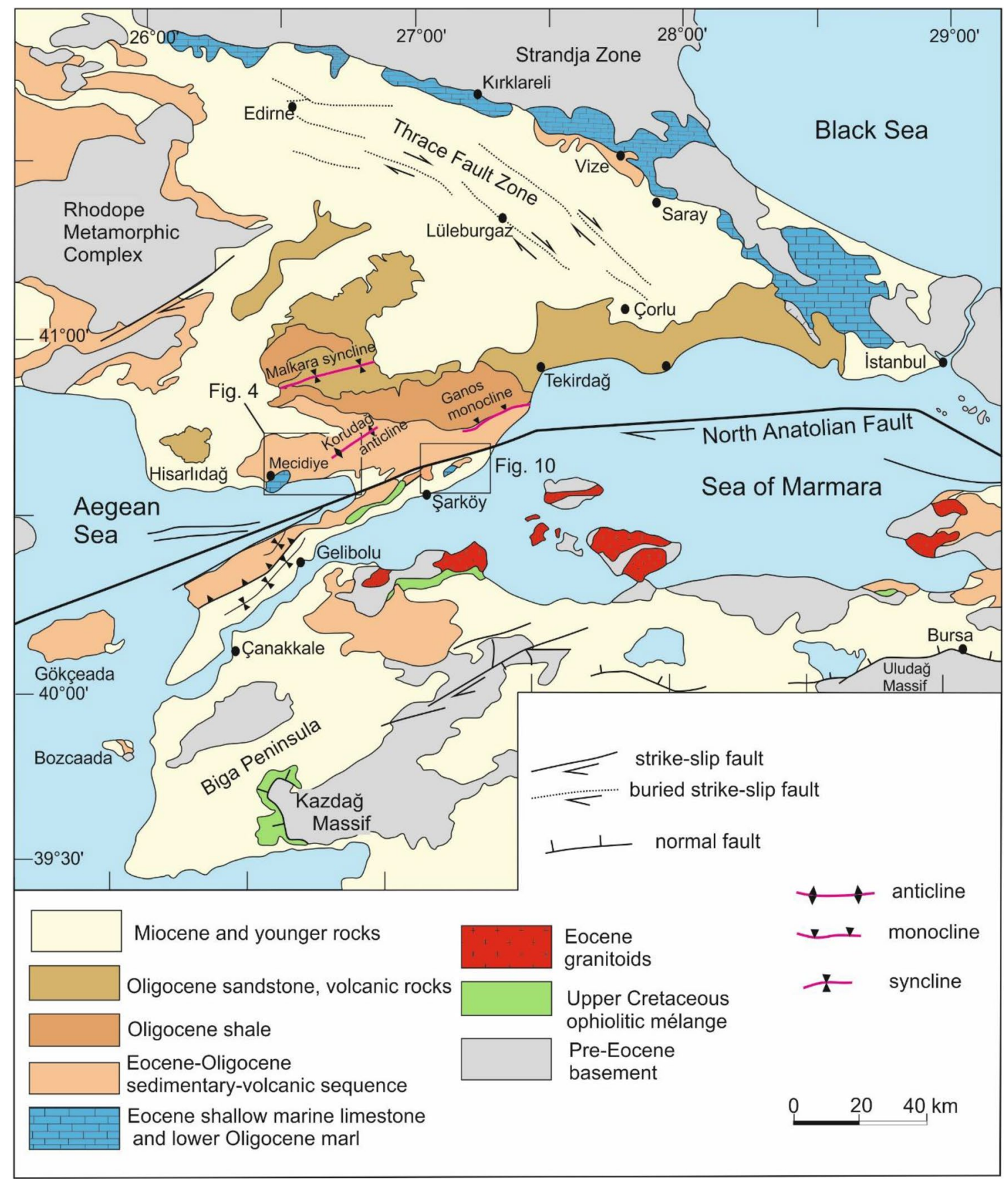

Fig. 2 Simplified geological map of northwest Turkey. Compiled from Türkecan and Yurtsever (2002), Okay et al. (2010) and Perincek (1991)

2007). Here we provide stratigraphic, geochronological and structural data for a phase of NNW-SSE shortening during the Late Oligocene-Early Miocene in the northern Aegean, and discuss its possible origin.

\section{Geological setting}

The Thrace Basin is a large, triangular-shaped hydro-carbonbearing Eocene-Oligocene basin in the northern Aegean
(Figs. 1, 2). It is filled with predominantly Middle Eocene to Upper Oligocene clastic sediments with thickness reaching up to $9 \mathrm{~km}$ in its centre (Kopp et al. 1969; Doust and Arıkan 1974; Turgut et al. 1991). The basin lies on the metamorphic rocks of the Strandja Zone and on the Circum-Rhodope belt in the east and west, respectively, and on the Upper Cretaceous ophiolitic rocks and blueschists in the south (Fig. 2; Siyako and Huvaz 2007; Topuz et al. 2008; Okay et al. 2010). Most of the Thrace Basin lies in Turkey, however, 


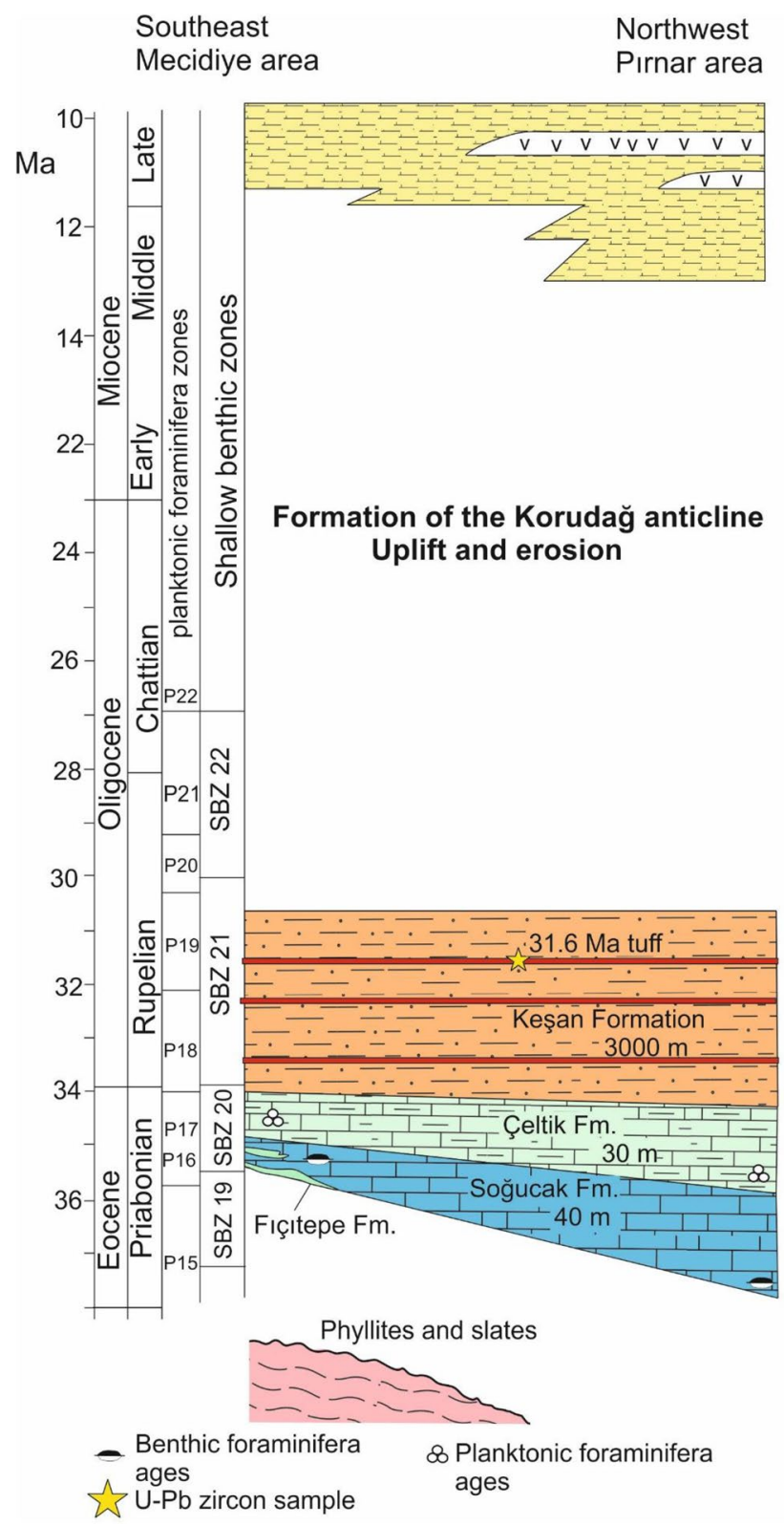

Fig. 3 Generalized stratigraphic section of the Korudağ region in southwestern Thrace Basin

its margins extend into Greece and Bulgaria (Boyanov and Goranov 2001; Cavazza et al. 2013; Caracciolo et al. 2015). The Thrace Basin was formed during Late Eocene to Early Oligocene extension, and coeval extensional basins and structures are described from the Rhodopes (Georgiev et al. 2010; Pleuger et al. 2011).

The basal deposits of the Thrace Basin consist of shallow marine Eocene limestones, the Soğucak Formation, locally with a thin basal clastic layer. The Soğucak Formation lies over the metamorphic rocks of the Strandja Zone, the Circum-Rhodope Belt and over the ophiolitic mélange (Fig. 2; Okay et al. 2010). It is dated as Middle to Late Eocene
(Bartonian and Priabonian) by large benthic foraminifera (Özcan et al. 2010; Less et al. 2011; Yücel et al. 2020). The Soğucak Formation is overlain by a thick clastic sequence of Late Eocene to Late Oligocene age (Fig. 3; Kopp et al. 1969; Sümengen and Terlemez 1991; Siyako and Huvaz 2007). The clastic sequence starts at the base with the siliciclastic turbidites, the Keşan Formation, which pass upwards into deltaic shales with sandstone beds, the Mezardere Formation, which are overlain by thickly bedded fluviatile to marginal marine sandstones and shales with coal layers; this Osmanc1k Formation constitutes the main gas reservoirs in the Thrace Basin (Turgut et al. 1991). The Eocene-Oligocene sedimentary rocks of the Thrace Basin are overlain unconformably by poorly consolidated Middle to Upper Miocene continental sandstones (Figs. 2, 3; Perincek 1991; Okay et al. 2020).

The Thrace Basin is intersected in the northeast by a Late Oligocene-Early Miocene dextral strike-slip fault zone, the Thrace Fault (Perincek 1991), which can be traced into Bulgaria as the Maritsa Fault (Gerdjikov and Georgiev 2006). In the south, the Thrace Basin is cut by the North Anatolian Fault, a post-Late Miocene dextral strike-slip fault (Fig. 2). The onland segment of the North Anatolian Fault in Thrace is called the Ganos Fault. The Marmara Sea has formed after the Late Miocene as a result of the activity of the North Anatolian Fault (e.g., Armijo et al. 1999; Okay et al. 2000).

The sedimentary rocks of the Thrace Basin were affected by two phases of shortening to transpressional deformation, which led to the formation of folds and faults. The first phase was in the Late Oligocene to Early Miocene prior to the deposition of the Miocene sandstones, and the second phase is related to the Late Miocene and younger activity of the North Anatolian Fault. The importance of these two phases and their relation are a matter of debate (e.g., Armijo et al. 1999; Yaltırak et al., 2000; Karakaş et al. 2018). We studied the structure and stratigraphy of the region north of the Bay of Saros, where one of the major folds of the Thrace Basin, the Korudağ anticline, is located (Fig. 2) with the aim of constraining the age and significance of the Late Oligocene-Early Miocene contractional deformation in the Thrace Basin.

\section{Methods}

The methods employed during this study include geological mapping, biostratigraphy and zircon U-Pb dating. Geological mapping was done on 1:25,000 scale topographic maps. Locations of the samples and observation points are given in UTM coordinates on the European 1979 Datum. Marl and pelagic limestone samples were studied for planktonic foraminifera. Samples were disaggregated using acetic acid/chloroform method modified after Knitter (1979) 
for obtaining isolated specimens. Taxonomic analyses are based mainly on Pearson et al. (2006) and the biozonation follows Berggren et al. (1995). Mineral separation was done in the Istanbul Technical University using classical techniques including crushing, sieving and magnetic separation. For zircon separation, we used sodium polytungstate as a heavy liquid. The zircons were picked under a stereographic microscope and mounted in epoxy and were polished. Zircons were analyzed using laser-ablation inductively coupled plasma mass spectrometry (LA-ICPMS) at the University of California, Santa Barbara. For the details of the method employed, see Kylander-Clark et al. (2013). Long-term reproducibility in secondary reference materials is $<2 \%$, and as such, should be used when comparing ages obtained within this analytical session, to ages elsewhere. The U-Pb analytical data are given in Table 1.

\section{Stratigraphy of the region north of the Saros Bay}

Phyllites and slates of the Circum-Rhodope Belt crop out in a small region north of the Saros Bay and constitute the basement (Figs. 3, 4; Okay et al. 2010). They are overlain by Eocene continental red conglomerates and sandstones of the Fiçıtepe Formation deposited in an alluvial fan, or directly by shallow marine limestones of the Soğucak Formation (Fig. 5a, b). The conglomerates and sandstones of the Fiçıtepe Formation pass upwards and interfinger with shallow marine limestones of the Soğucak Formation (Fig. 5b).
The Soğucak Formation consists of thickly bedded to massive, cream to light-grey, fossiliferous shallow marine limestones and has a maximum thickness of about $50 \mathrm{~m}$ (Fig. $5 \mathrm{c}$ ). It crops out mainly along the coast of the Saros Bay close to the village of Mecidiye; there is also a small inlier of the Soğucak Formation around the village of Pirnar (Fig. 4). The Soğucak Formation contains corals, bivalves, algae and larger benthic foraminifera. The latter indicates a late Middle to Late Eocene (upper Bartonian-Priabonian) age corresponding to the Shallow Benthic Zones (SBZ) 18A$18 \mathrm{~B}$ in the Pirnar area and latest Eocene age (SBZ20) in the Mecidiye region (Fig. 3; Özcan et al. 2010; Yücel et al. 2020).

In the Mecidiye and Pirnar regions, the Soğucak Formation is overlain by a thin sequence of pelagic marl and marly limestones, which are named here as the Çeltik Formation (Fig. 4). These pelagic limestones were first described by Ternek (1949), who assigned them an Upper Cretaceous age; later Yaltırak et al. (2002) assigned an Early Paleocene to Early Eocene age to the Çeltik Formation. Both studies regarded the Çeltik Formation lying stratigraphically below the Soğucak Formation, however, our mapping has shown that the Çeltik Formation lies above the Soğucak Formation, and below the turbidites of the Keşan Formation (Fig. 4). This is also supported by the paleontological determinations (see below). The confusion regarding the stratigraphic position of the Çeltik Formation arises from poor outcrops in the Çeltik region, where the pelagic limestones were

Table 1 LA-ICPMS U-Pb isotopic data for zircons from the acidic tuff bed in the Keşan Fornation

\begin{tabular}{|c|c|c|c|c|c|c|c|c|c|c|c|c|c|}
\hline U ppm & Th ppm & ${ }^{207} \mathrm{~Pb} /{ }^{235} \mathrm{U}$ & $2 \sigma$ & ${ }^{206} \mathrm{~Pb} /{ }^{238} \mathrm{U}$ & $2 \sigma$ & Rho & ${ }^{238} \mathrm{U} /{ }^{206} \mathrm{~Pb}$ & $2 \sigma$ & ${ }^{207} \mathrm{~Pb} /{ }^{206} \mathrm{~Pb}$ & $2 \sigma$ & rho & Age & Concordance \\
\hline 225 & 165 & 0.473 & 0.064 & 0.009 & 0.0007 & 0.99 & 115.21 & 8.68 & 0.401 & 0.033 & 0.44 & 30.6 & 0.14 \\
\hline 259 & 194 & 0.038 & 0.003 & 0.005 & 0.0002 & 0.50 & 201.90 & 6.47 & 0.056 & 0.004 & 0.23 & 31.5 & 0.85 \\
\hline 399 & 352 & 0.046 & 0.005 & 0.005 & 0.0002 & 0.85 & 198.02 & 6.56 & 0.066 & 0.006 & 0.15 & 31.7 & 0.71 \\
\hline 398 & 418 & 0.034 & 0.002 & 0.005 & 0.0002 & 0.06 & 207.25 & 6.52 & 0.051 & 0.002 & 0.21 & 30.8 & 0.91 \\
\hline 252 & 214 & 0.046 & 0.004 & 0.005 & 0.0002 & 0.19 & 195.50 & 6.17 & 0.066 & 0.006 & 0.31 & 32.1 & 0.72 \\
\hline 635 & 609 & 0.067 & 0.013 & 0.005 & 0.0002 & 0.97 & 183.49 & 6.63 & 0.088 & 0.014 & 0.13 & 33.2 & 0.53 \\
\hline 550 & 449 & 0.680 & 0.281 & 0.010 & 0.0024 & 1.00 & 96.15 & 22.38 & 0.408 & 0.075 & 0.48 & 36.0 & 0.13 \\
\hline 231 & 135 & 0.190 & 0.015 & 0.026 & 0.0008 & 0.85 & 38.80 & 1.23 & 0.054 & 0.004 & 0.23 & 163.1 & 0.93 \\
\hline 161 & 72 & 0.235 & 0.029 & 0.025 & 0.0008 & 0.89 & 39.28 & 1.26 & 0.067 & 0.007 & 0.07 & 158.5 & 0.76 \\
\hline 242 & 367 & 0.059 & 0.009 & 0.005 & 0.0002 & 0.90 & 193.42 & 7.34 & 0.081 & 0.011 & 0.14 & 31.8 & 0.57 \\
\hline 365 & 329 & 0.133 & 0.019 & 0.006 & 0.0003 & 0.99 & 176.68 & 8.19 & 0.169 & 0.019 & 0.17 & 30.7 & 0.29 \\
\hline 378 & 379 & 0.032 & 0.001 & 0.005 & 0.0002 & 0.08 & 203.33 & 6.37 & 0.048 & 0.002 & 0.29 & 31.6 & 0.99 \\
\hline 347 & 303 & 1.840 & 0.160 & 0.020 & 0.0014 & 1.00 & 49.02 & 3.45 & 0.650 & 0.018 & 0.58 & 30.1 & 0.12 \\
\hline 473 & 452 & 0.480 & 0.131 & 0.009 & 0.0021 & 1.00 & 106.38 & 23.98 & 0.369 & 0.057 & 0.66 & 35.6 & 0.15 \\
\hline 303 & 210 & 0.345 & 0.057 & 0.008 & 0.0005 & 1.00 & 129.87 & 9.14 & 0.315 & 0.031 & 0.38 & 32.6 & 0.16 \\
\hline 414 & 467 & 2.180 & 0.872 & 0.023 & 0.0075 & 1.00 & 43.48 & 14.24 & 0.614 & 0.057 & 0.63 & 40.8 & 0.12 \\
\hline 488 & 641 & 0.835 & 0.067 & 0.012 & 0.0006 & 0.98 & 83.19 & 4.32 & 0.508 & 0.020 & 0.44 & 31.8 & 0.12 \\
\hline 228 & 227 & 0.230 & 0.024 & 0.007 & 0.0003 & 0.97 & 153.37 & 6.58 & 0.255 & 0.018 & 0.32 & 30.8 & 0.20 \\
\hline 410 & 473 & 0.282 & 0.096 & 0.007 & 0.0008 & 1.00 & 143.68 & 17.47 & 0.271 & 0.060 & 0.31 & 31.9 & 0.18 \\
\hline 337 & 284 & 0.049 & 0.002 & 0.005 & 0.0002 & 0.08 & 197.24 & 6.11 & 0.070 & 0.003 & 0.22 & 31.6 & 0.67 \\
\hline
\end{tabular}




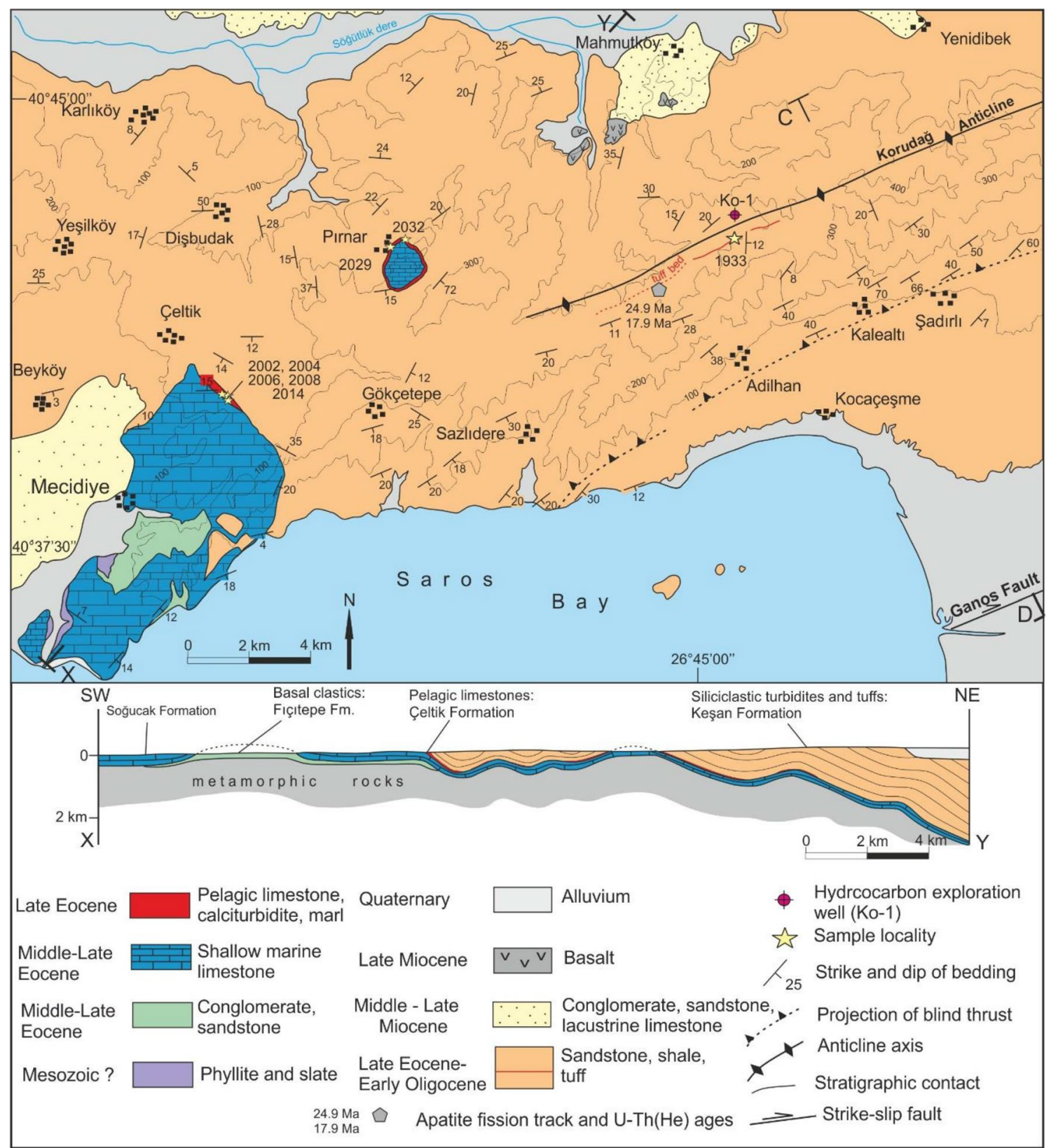

Fig. 4 Geological map and cross-section of the Korudağ region. For cross-section along line CD see Fig. 9. For location see Fig. 2

first described by Ternek (1949) and later by Yaltırak et al. (2002). On the other hand, in the Pırnar region, the Çeltik Formation lies with a clear stratigraphic contact over the Soğucak Formation. Yaltırak et al. (2002) do not give any fossil list or photographs for the "Early Paleocene to Early Eocene" age of the Çeltik Formation. Ternek (1949) provides a short fossil list and thin section photographs of some of these "Upper Cretaceous" foraminifera. However, according to micropaleontologists Aynur Hakyemez and Demir Altıner (personal communication) there are no definite Cretaceous foraminifera on the photographs; the foraminifera on the photographs are mostly of Cenozoic age. Therefore, we conclude that earlier paleontological determinations from the Çeltik Formation were incorrect.

The Çeltik Formation consists of light pink, light brown, beige, thinly bedded glauconite-bearing pelagic limestones with marl and calciturbidite interbeds (Fig. 5d). It crops out both in the Mecidiye and Pirnar regions and has an estimated maximum thickness of about $30 \mathrm{~m}$. Five samples from the Mecidiye area and two samples from the Pirnar were studied paleontologically. All samples contain a rich fauna of Upper Eocene planktonic foraminifera (Fig. 6). The fauna 

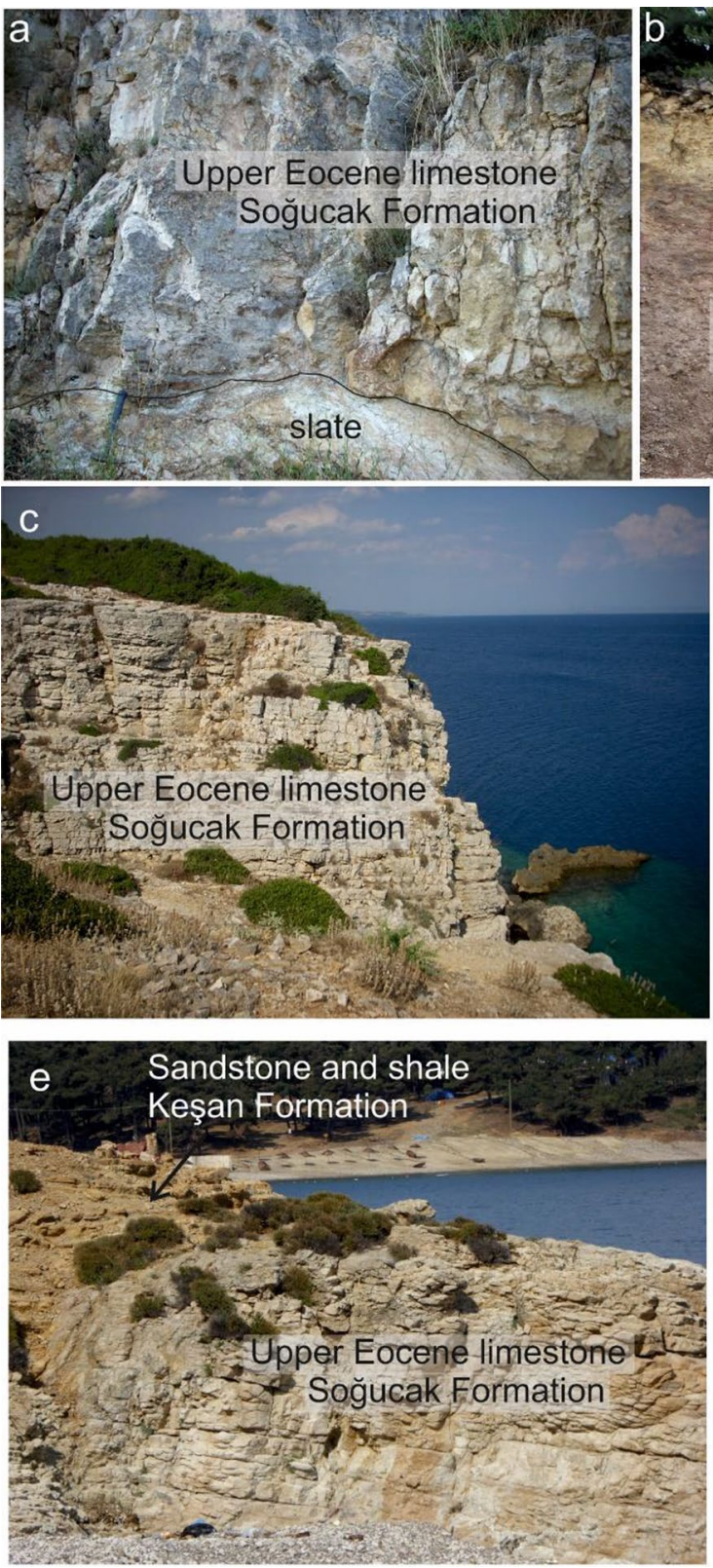

Fig. 5 a Upper Eocene limestones of the Soğucak Formation lying unconformably over the metamorphic basement, Mecidiye area. b Upper Eocene conglomerates overlain by the Upper Eocene limestones of the Soğucak Formation, Mecidiye area. c Medium bedded shallow marine Upper Eocene limestones of the Soğucak Formation,

in the Mecidiye samples (2002, 2004, 2006, 2008B and 2014) indicates a latest Eocene age, specifically planktonic foraminifera zones P16 (upper) and P17 (Figs. 3, 6). Samples of the Çeltik Formation from the Pırnar area (2029A and 2032) have also a similar fauna of planktonic foraminifera (Figs. 6, 7). The presence of Globigerinatheka species, not recorded in the Mecidiye samples, however, indicates a slightly older Late Eocene age for the Çeltik Formation in the Pirnar area, namely zones P15 (upper)-P 16 (lower).
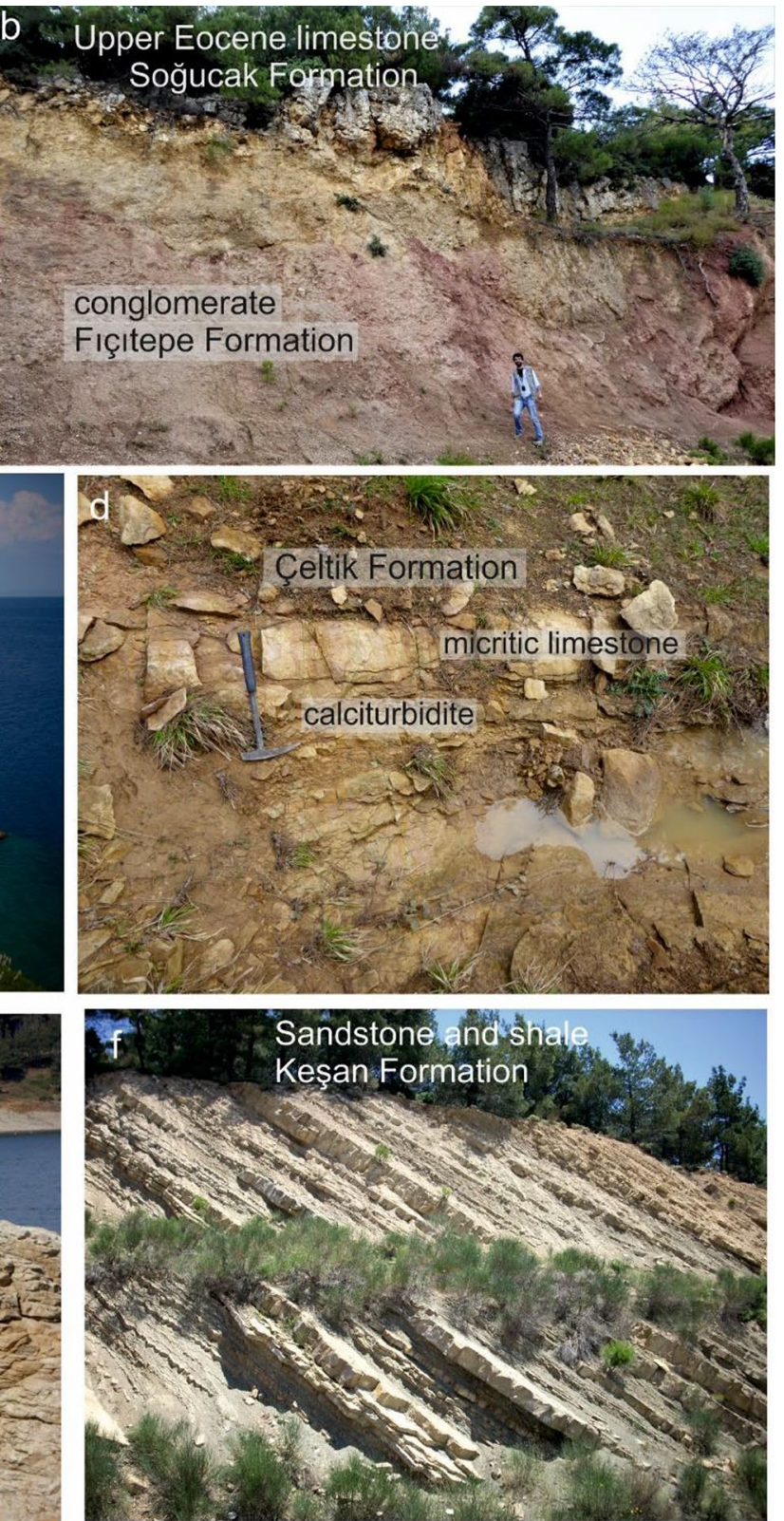

Mecidiye area. d Upper Eocene pelagic limestone and calciturbidite of the Çeltik Formation, Çeltik area. e Upper Eocene limestones of the Soğucak Formation overlain by the sandstones and shales of the Keşan Formation, Mecidiye area. f Turbiditic sandstones and shales of the uppermost Eocene-Lower Oligocene Keşan Formation

Çeltik Formation is not present in some areas such as south of Mecidiye, where the Soğucak Limestone is directly overlain by the sandstones of the Keşan Formation (Figs. 4, 5e; Yücel et al. 2020). The Keşan Formation is a thick sequence $(>2 \mathrm{~km})$ of siliciclastic marine turbidites, which lies stratigraphically over the Soğucak and Çeltik formations (Fig. 3; Sümengen and Terlemez 1991; Şentürk et al. 1998). The Korudağ-1 exploration well (Ko-1 in Fig. 2), drilled on the axis of the Korudağ anticline has cut 


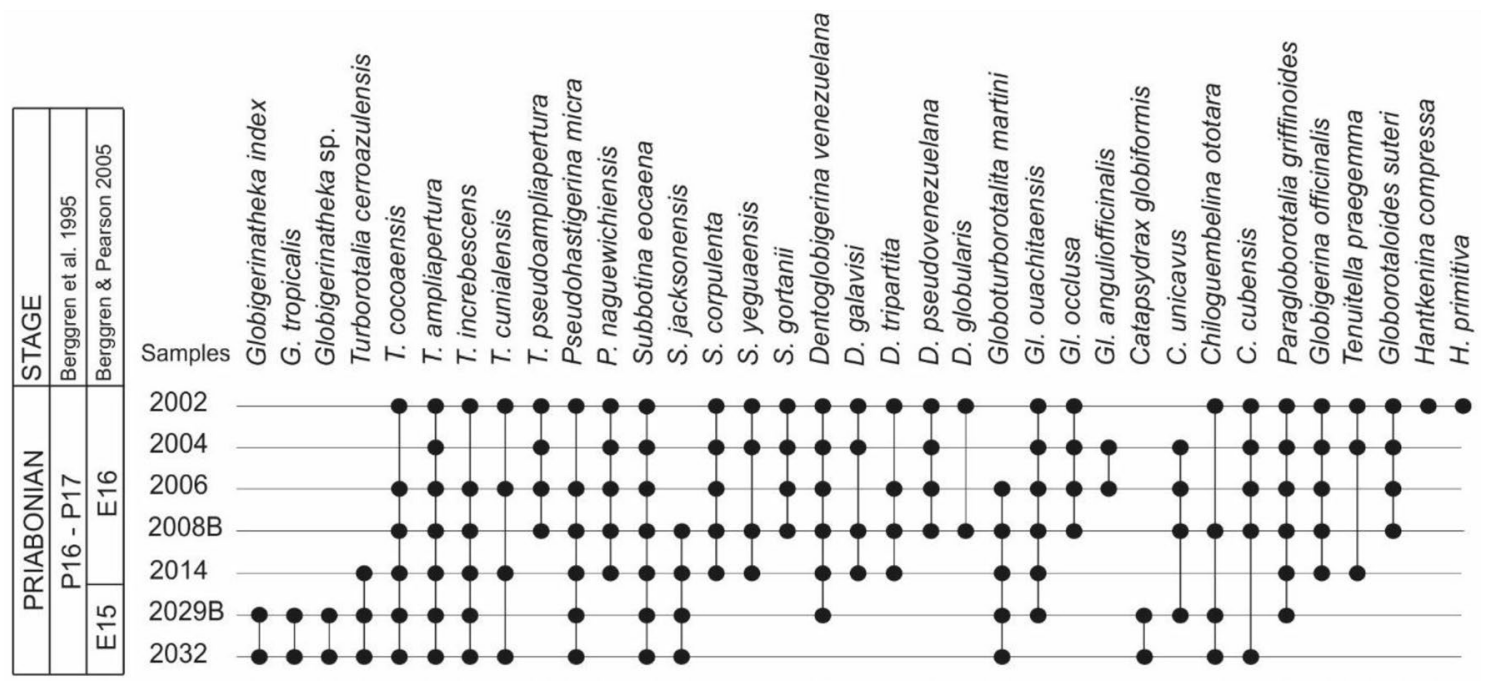

Fig. 6 Distribution of planktonic foraminifera in the samples from the Upper Eocene Çeltik Formation

through $2351 \mathrm{~m}$ of Keşan Formation without entering the Upper Eocene limestones of the Soğucak Formation (Şen and Yillar 2009).

In the Korudağ area, the Keşan Formation consists of medium to thickly bedded, medium to coarse-grained, brown, yellowish-brown sandstones and intercalated shales representing proximal to medial turbidites (Fig. 5f). There are also white, pale grey tuff beds in the Keşan Formation, which probably represent welded air fall ash deposits. A white, porous, laterally continuous tuff bed (sample 1933) from the stratigraphically upper parts of the Keşan Formation, was sampled for zircon dating. Twenty zircon grains from the tuff sample (1933) were dated, two zircons produced a Jurassic age; the rest are predominantly Early Oligocene and yielded a U-Pb age of 31.6 $\pm 0.4 \mathrm{Ma}$ (Table 1, Fig. 8). The age of the tuff and that of the underlying Çeltik Formation constrains the age of the Keşan Formation to the latest Eocene and Early Oligocene (latest Priabonian-Early Rupelian).

In the Korudağ region, the Keşan Formation is unconformably overlain by poorly consolidated Miocene continental conglomerates, sandstones, lacustrine limestones intercalated with basaltic flows (Fig. 4). Lacustrine sediments around Yenidibek (Pişmanköy) and Mahmutköy villages have yielded Middle Miocene (MN6, ca.13 Ma) and Late Miocene (Vallesian, mammal age MN9, ca. $11 \mathrm{Ma}$ ) micro-mammals, respectively (Ünay and de Bruijn 1984). $\mathrm{Ar}-\mathrm{Ar}$ whole-rock age from basaltic rocks is $8.5 \pm 0.4 \mathrm{Ma}$ (Kaymakc1 et al. 2007).

\section{The structure: Korudağı Anticline}

The Korudağ forms an ENE-WSW trending topographic ridge, whose crest corresponds approximately to the hinge line of a large south-vergent asymmetrical anticline, the Korudağ anticline (Figs. 4, 9). The folding has affected Eocene-Oligocene sequences and occurred before the deposition of the Middle Miocene continental sequence (Fig. 4). The Koruda $\breve{g}$ anticline is a $22 \mathrm{~km}$ long and 9 $\mathrm{km}$ wide, cylindrical, asymmetric open fold with a subhorizontal fold axis trending $\mathrm{N} 65^{\circ} \mathrm{E}$ and plunging $\sim 2^{\circ}$ to the NE (Fig. 9). The dips of the limbs are $30^{\circ}$ or less, except in a zone of subvertical dips in the south. This steep zone is also apparent in the satellite imagery (Fig. 9a). No minor or parasitic folds are observed in the Korudag anticline, and there is no cleavage in the Eocene-Oligocene turbidites. The geometry of the fold, and specially the zone of steep dips on the southern limb suggest that the Korudağ anticline is a fault-propagation fault formed at the tip of a propagating blind thrust (Fig. 9b, e.g., Suppe and Medvedeff 1990). A geological cross-section based on surface data and incorporating well data from Ko-1 across the Korudağ anticline indicates about one kilometer of NNW-SSE $\left(\mathrm{N} 25^{\circ} \mathrm{W}\right)$ shortening.

The Korudağ anticline is not the only major Cenozoic fold in the Thrace Basin. There are two other major folds similar in scale to the Korudağ anticline: the Malkara syncline and the Ganos monocline. The Malkara syncline is a poorly exposed gentle fold (Fig. 2). The well-exposed Ganos monocline is located in the southern Thrace Basin north of the North Anatolian Fault (Fig. 2). It is $35 \mathrm{~km}$ long and $10 \mathrm{~km}$ wide with a steep southern limb and subhorizontal northern limb; the fold axis trends $\mathrm{N} 69^{\circ} \mathrm{E}$ and plunges at $4^{\circ}$ to the southwest, similar to the $\mathrm{N} 65^{\circ} \mathrm{E}$ trend and $2^{\circ}$ NE plunge of the Korudağ fold axis (Fig. 9; Okay et al. 2004). The folding has affected the Eocene-Oligocene turbidites and the minimum shortening is estimated to be $3.5 \mathrm{~km}$. 


\section{Late Oligocene-Early Miocene shortening and inversion of the Thrace Basin}

Late Oligocene-Early Miocene folding in the Thrace Basin was associated with the uplift, exhumation and the inversion of the Thrace Basin. In the southern Thrace Basin, south of the Ganos Fault, the folded Eocene-Oligocene sedimentary rocks are overlain over large regions with a marked angular unconformity by the Lower-Middle Miocene continental sandstones and conglomerates (Figs. 10, 11; Okay et al. 2010; Ünay and de Bruijn 1984). In many areas, the Eocene-Oligocene siliciclastic turbidites are completely eroded and the Miocene sediments rest on the Soğucak Formation or directly on the ophiolitic basement. In the central and northern Thrace Basin folded and faulted Eocene-Oligocene sequences are also overlain unconformably by Miocene sandstones (Perincek 1991).

The timing of shortening in the Thrace Basin is constrained between the end of the Eocene-Oligocene sedimentation and the deposition of the continental Miocene sequences. In the Korudağ region, the youngest known age from the Eocene-Oligocene succession is the Early Oligocene tuff, ca. 31.6 Ma. In the region of the Ganos Mountain and also around Tekirdağ, the turbidites of the Keşan Formation shallow-upwards, and pass up into deltaic shales (the Mezardere Formation), which are overlain by paralic sandstones and shales with lignite and tuff seams (Osmanc1k Formation) (Fig. 12; Turgut et al. 1991; Okay et al. 2004). Mammal and ostracoda fossils in the Osmancik Formation, and the tuff zircon $\mathrm{U}-\mathrm{Pb}$ ages indicate an early Late Oligocene age for the Osmancik Formation (ca. $28 \mathrm{Ma}$, Lebküchner 1974; Şafak and Güldürek 2016; Okay et al. 2019). In the central and northern Thrace Basin, including the Korudağ region, the Eocene-Oligocene sequences are unconformably overlain by Middle-Upper Miocene fluviatile sandstones, lacustrine limestones and basalts of the Ergene Formation. These data constrain the shortening and inversion in the central and northern Thrace Basin to the Late Oligocene to Middle Miocene (28-13 Ma, Fig. 12).

Late Oligocene-Early Miocene exhumation in the Thrace Basin is also indicated by the thermochronological data. Apatite fission track (AFT) and apatite U-Th/He ages from the crest of the Korudağ anticline are 24.9 Ma and 17.9 Ma, respectively (Fig. 12; Zattin et al. 2005, 2010). The AFT age from the Keşan Formation is younger than its depositional age, which indicates that the Keşan Formation was buried by more than $\sim 3 \mathrm{~km}$ before its exhumation in the Late Oligocene and Early Miocene. The timing of exhumation constrained by the thermochronological data is compatible with that deduced from the stratigraphy and is most likely linked to the formation of the Korudag anticline.

The post-shortening Miocene sequences are older in the southern Thrace Basin, south of the Ganos Fault; they are dated to Late Early Miocene (Burdigalian) and Middle Miocene (ca. 17-14 Ma) by micro-mammals (Ünay and de Bruijn 1984). Thermochronological data from across the Ganos Fault indicate that the Ganos monocline formed during the Middle Miocene between 16 and 9 Ma (Fig. 12; Zattin et al. 2005, 2010), later than the Korudağ anticline.

\section{The North Anatolian Fault and the deformation in the Thrace Basin}

There is a general agreement that the North Anatolian Fault is a Late Miocene and younger (post $5 \mathrm{Ma}$ ) structure, which accommodates the westward translation of Anatolia (e.g., Şengör 1979; Barka 1992). Hence, the Late Oligocene-Early Miocene shortening in the Thrace Basin cannot have a causal link to the activity of the present North Anatolian Fault. However, Armijo et al. (1999) and Karakaş et al. (2018) claim that the folding in the Thrace Basin is caused by the Late Miocene-Earliest Pliocene (5.6-5.0 Ma) activity of the North Anatolian Fault. They invoke continuous sedimentation in the southern Thrace Basin from Eocene to Miocene despite the fact that all geologists, who have worked in the region, have mapped a major angular unconformity between the Eocene-Oligocene sequence and the overlying Miocene continental sediments (Figs. 3, 9, 10; Kopp et al. 1969; Sümengen and Terlemez 1991; Tüysüz et al. 1998; Şentürk et al. 1998; Okay et al. 2004). Thermochronological data from the Ganos monocline also indicate that the uplift took place in the Middle Miocene (ca. 16-9 Ma) well before the inception of the North Anatolian Fault. The Late Oligocene-Early Miocene shortening in the northern Aegean is not related to the activity of the North Anatolian Fault (Zattin et al. 2005, 2010).

\section{Cause of the Late Oligocene-Early Miocene shortening in the northern Aegean}

The Thrace Basin was formed during a period of extension in the Late Eocene and Oligocene. Coeval extension is described from the Rhodopes with the creation of several smaller and mostly continental basins locally bounded by detachment faults (Burchfiel et al. 2008; Georgiev et al. 2010; Pleuger et al. 2011; Kilias et al. 2013). In the Thrace Basin, the extension was followed by NNW-SSE shortening constrained between 28 and $17 \mathrm{Ma}$ (Late Oligocene-Early Miocene), which led to the termination of sedimentation. On the island of Limnos on the southwestern corner of the Thrace Basin (Fig. 1), Innocenti et al. (1994) also describe Late Oligocene-Early Miocene shortening characterized by folds with ENE trending axis. Dumurdzanov et al. (2005) and Burchfiel et al. (2008) also describe latest Oligocene-Early Miocene shortening in Macedonia and western Bulgaria. In the Rhodopes Late Oligocene-Early Miocene 


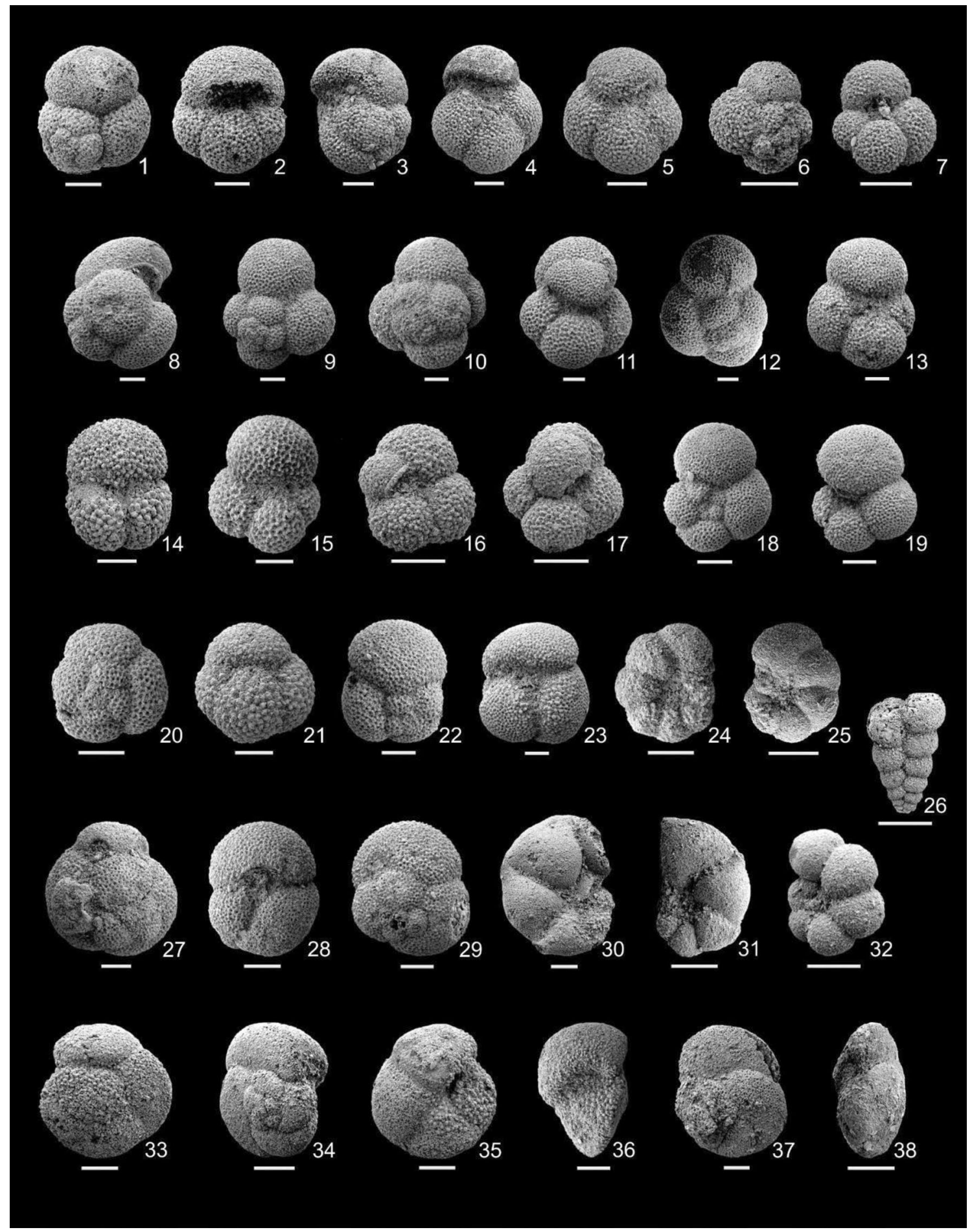

Fig. 7 Scanning Electron Microscope (SEM) images of planktonic foraminifera from the Upper Eocene Çeltik Formation. 1-3. Turborotalia ampliapertura (Bolli), 2004; 4. Turborotalia pseudoampliapertura (Blow \& Banner), Mecidiye 2002; 5. Turborotalia increbescens (Bandy), 2004; 6-7. Globoturborotalita ouachitaensis (Howe \& Wallace), Mecidiye 2008B; 8. Subbotina gortanii (Borsetti), Mecidiye 2002; 9-11. Subbotina corpulenta (Subbotina), Mecidiye 2008B; 12-13. Subbotina eocaena (Gümbel), Mecidiye 2004; 14. Dentoglobigerina galavisi (Bermúdez), Mecidiye 2004; 15. Dentoglobigerina globularis (Bermúdez), Mecidiye 2008B; 16. Globorotaloides suteri Bolli, Mecidiye 2014; 17. Globoturborotalita martini (Blow \& Banner), Mecidiye 2014; 18-19. Paragloborotalia griffinoides (Olsson \& Pearson), Mecidiye 2014; 20-21. Dentoglobigerina venezuelana (Hedberg), Mecidiye 2014; 22-23. Dentoglobigerina tripartita (Koch), Mecidiye 2008B; 24. Pseudohastigerina naguewichiensis (Myatliuk), Mecidiye 2006; 25. Pseudohastigerina micra (Cole), Mecidiye 2014; 26. Chiloguembelina ototara (Finlay), Mecidiye 2004; 27. Globigerinatheka sp., Pirnar 2032; 28-29. Globigerinatheka index (Finlay), Pirnar 2029B; 30. Hantkenina compressa Parr, Mecidiye 2002; 31. Hantkenina primitiva Cushman \& Jarvis, Mecidiye 2002; 32. Tenuitella praegemma (Li), Mecidiye 2014; 33-36. Turborotalia cocoaensis (Cushman), Mecidiye 2014; 37-38. Turborotalia cunialensis (Toumarkine \& Bolli), Mecidiye 2006. Scale bar: $100 \mu \mathrm{m}(1-23,25-38)$; 50 $\mu \mathrm{m}$ (24) 
was apparently a tectonically quiet period between two extensional phases of Late Eocene-Oligocene and Miocene ages, respectively (Georgiev et al. 2010).

The temporal and spatial relation between Late Oligocene-Early Miocene shortening and Cenozoic extension in the Aegean is complex. Major crustal extension during the Late Eocene-Oligocene led to the formation of sedimentary basins including the Thrace Basin, and to the exhumation of Central Rhodopes in the northern Aegean (e.g., Georgiev et al. 2010; Kounov et al. 2020). Stratigraphic data and thermochronology constrain this first period of extension to 37 to $27 \mathrm{Ma}$. The second period of the extension during the Miocene is documented in metamorphic core complexes such as Kazdağ Massif and Southern Rhodopes (Dinter et al. 1995; Cavazza et al. 2009; Kounov et al. 2015) and associated sedimentary basins. Unlike the Late Eocene-Oligocene extension, the Miocene extension has affected the whole of Aegean. In the northern Aegean it is constrained between about 21 and $11 \mathrm{Ma}$ (Fig. 12, Cavazza et al. 2009; Kounov et al. 2015). The formation of Korudağ anticline and the termination of sedimentation in the Thrace Basin fills the gap between these two extensional phases with some apparent overlap possibly caused by age uncertanties (Fig. 12). Late Oligocene-Early Miocene represents a phase of minor shortening between two more intense extensional periods.

The Eocene to Present crustal extension in the Aegean is linked to the southward migration of the Hellenic trench (e.g., Le Pichon and Angelier 1979; Jolivet et al. 2013; Brun et al. 2016). In the first extensional period during the Eocene and Oligocene, extension was confined to the northern Aegean, whereas it effected the whole of Aegean during
Miocene and later. This change is attributed to an increase in the rate of trench retreat (Brun et al. 2016). The Late Oligocene-Early Miocene shortening was possibly also related to a change in plate kinematics. This view is supported by shortening directions, which are perpendicular to the trend of the subduction zone (Fig. 1 inset). In Macedonia and western Bulgaria the shortening is at ENE-WSW direction at right angles to that observed in the Thrace Basin but perpendicular to the trench (Dumurdzanov et al. 2005, Burchfiel et al. 2008). In the Thrace Basin the shortening direction is also perpendicular to the central Hellenic subduction zone. We suggest that a change in the subduction parameters, possibly a temporary shallowing of the subducting slab, caused minor shortening in the overriding plate that is recorded as regional folds in the northern Aegean.

\section{Conclusions}

The sedimentation in the Thrace Basin north of the Saros Bay started in the Middle-Late Eocene (Bartonian-Priabonian) with the deposition of shallow marine carbonates, which are overlain by a thin sequence of Upper Eocene pelagic limestones, previously considered as Late Cretaceous or Paleocene in age. The carbonates are overlain by a thick $(>3 \mathrm{~km})$ sequence of uppermost Eocene-Lower Oligocene siliciclastic marine turbidites with acidic tuff beds. Zircons from a tuff bed in the upper part of the sequence produced a $\mathrm{U}-\mathrm{Pb}$ age of $31.6 \pm 0.4 \mathrm{Ma}$. The turbidites are unconformably overlain by Middle to Upper Miocene continental sandstones and basalts.
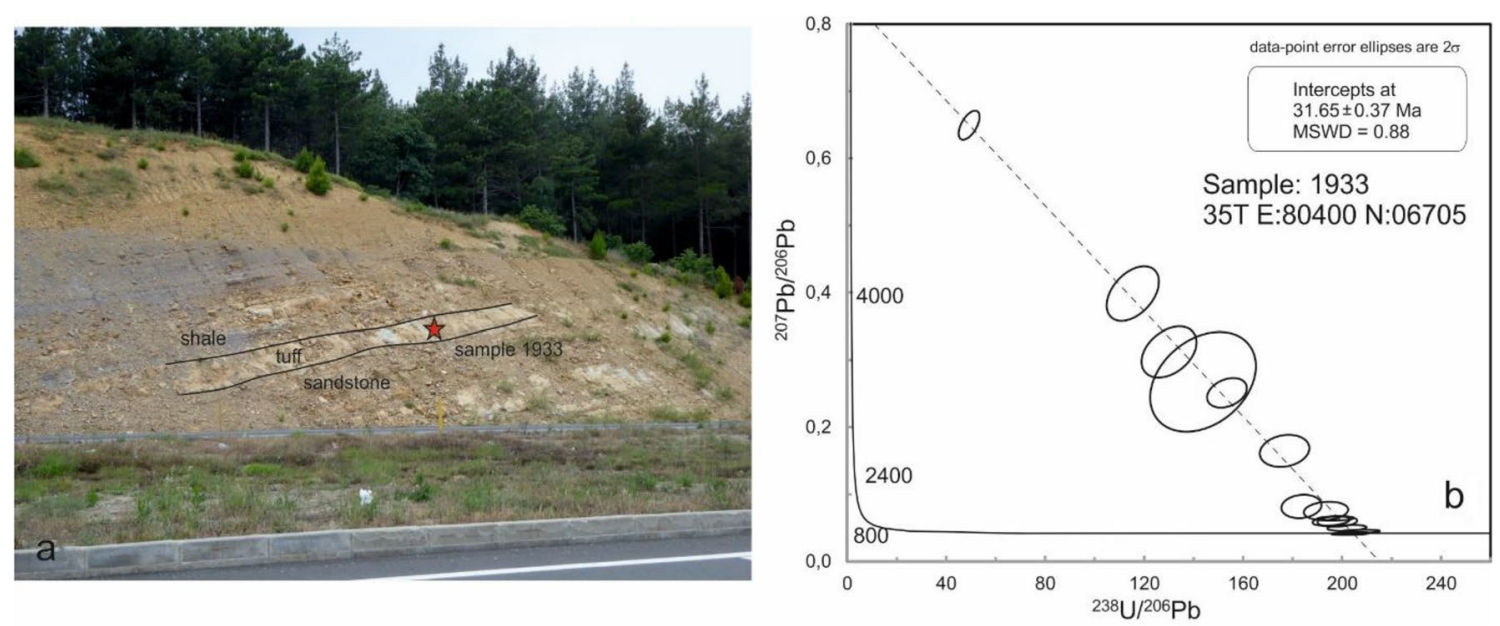

Fig. 8 a Dated tuff bed intercalated with sandstone-shale of the Keşan Formation. b Zircon U-Pb concordia diagram of the Lower Oligocene tuff sample. Location of the sample is shown in Fig. 4 

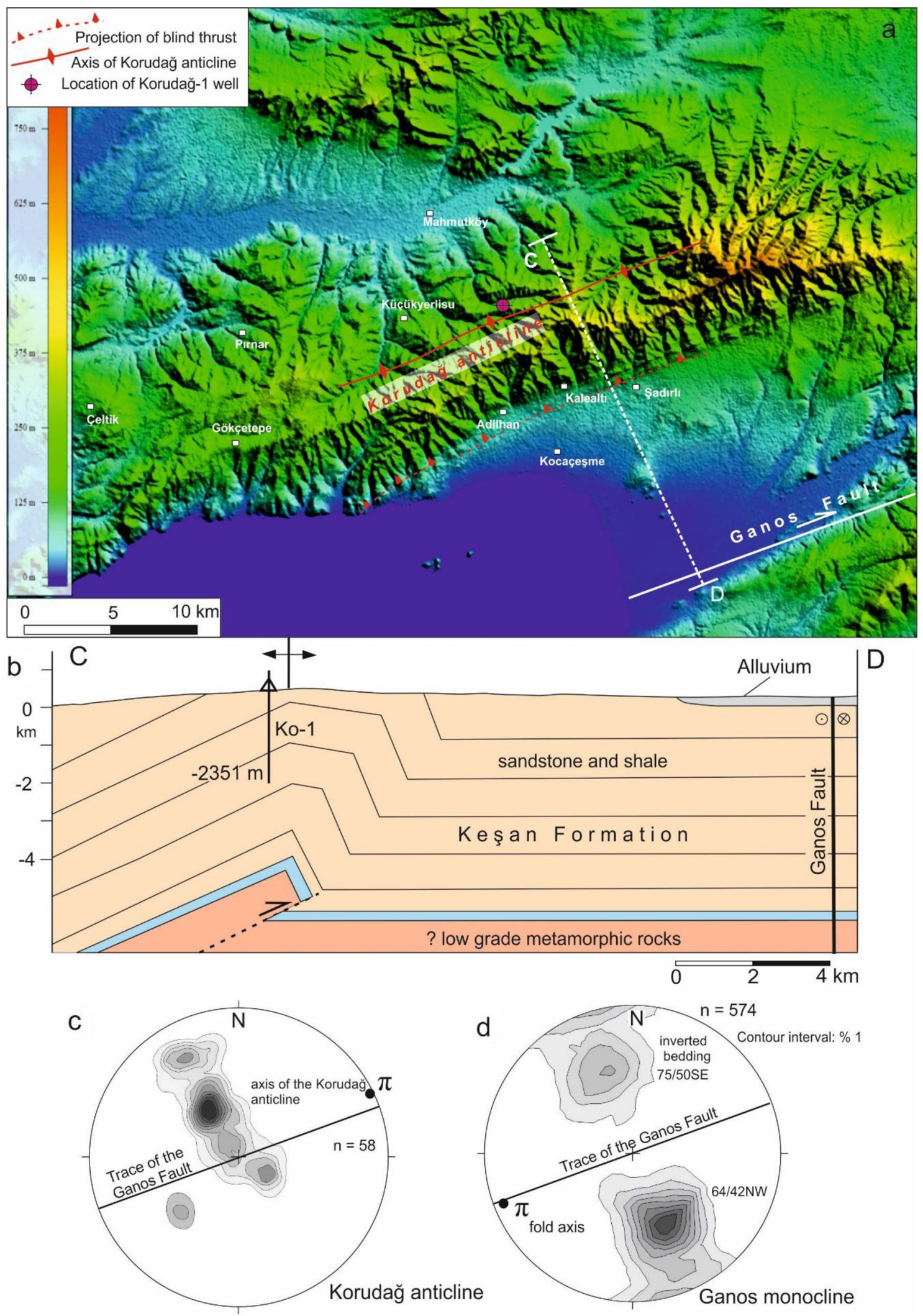

Fig. 9 a Digital elevation model of the Korudağ anticline (www.earthexplorer.usgs.com). b Cross-section of the Korudağ anticline. For the line of the cross-section see also Fig. 4. c-d Lower hemisphere equal-area projections of bedding from the Korudağ anticline and Ganos monocline 


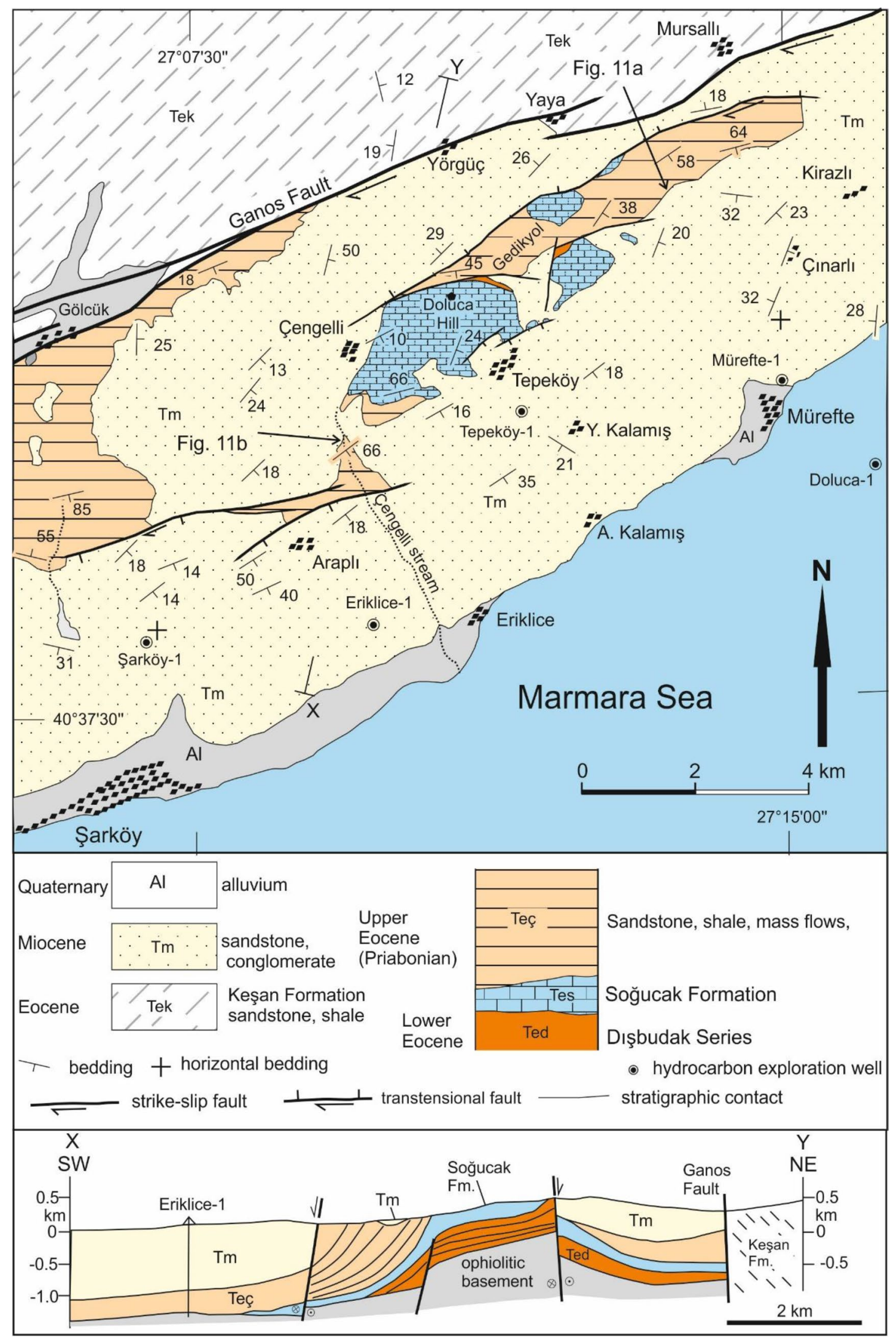

Fig. 10 Geological map and cross-section of southern Thrace. Note the major unconformity between the continental Miocene sandstones and the underlying Eocene-Oligocene sequence. For location see Fig. 2 (modified from Okay et al. 2010) 

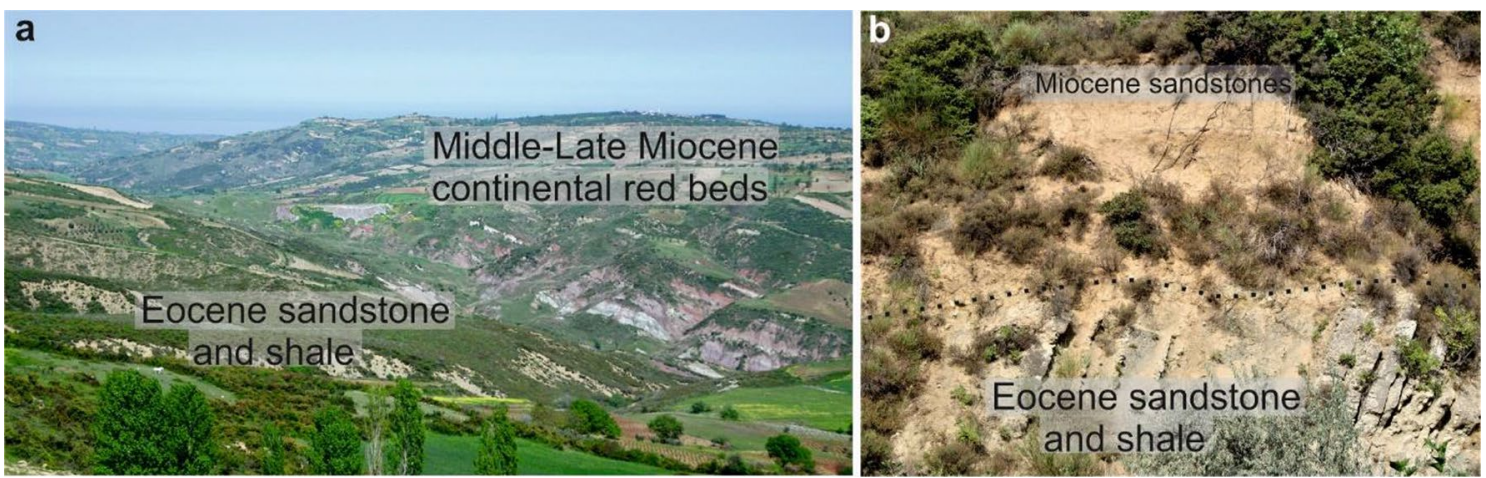

Fig. 11 Photographs of the Miocene unconformity. a Variegated basal sandstones and conglomerates of the Lower-Middle Miocene series lying unconformably over the Eocene-Oligocene siliciclastic turbidites. b Angular unconformity between the steeply dipping
Eocene-Oligocene sandstones and shales and subhorizontal Middle Miocene sands. The locations of the photographs are indicated in the map in Fig. 10

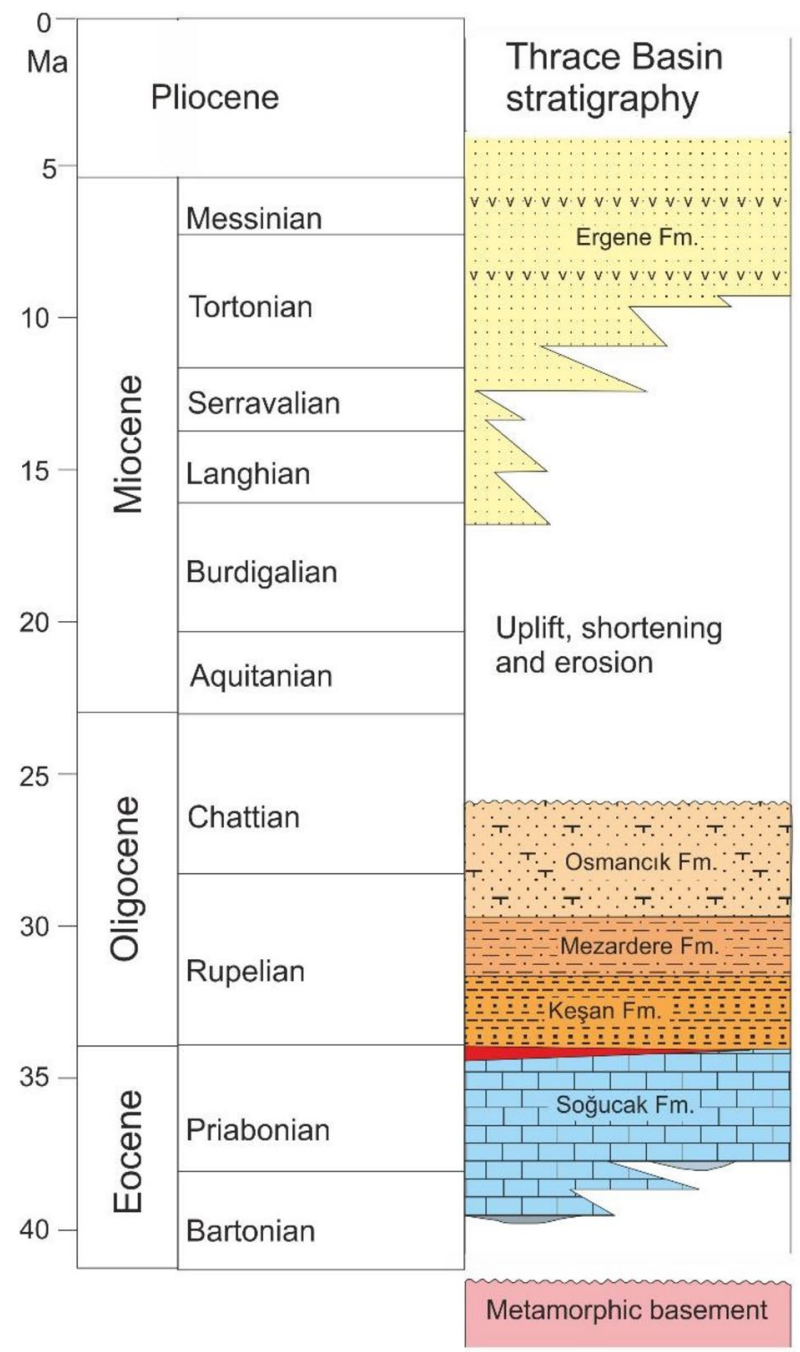

Inception of the North Anatolian Fault

Shortening

Extension

$19 \mathrm{Ma}$

Southern

Rhodope

Formation of the

Ganos monocline

$16 \mathrm{Ma}$

$18 \mathrm{Ma}$

Formation of the

Korudağ anticline

Regional shortening

$25 \mathrm{Ma}$

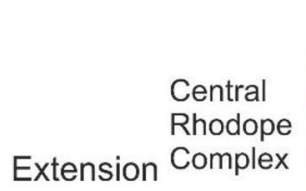

Fig. 12 Stratigraphy of the Thrace Basin and episodes of shortening and extension in the northern Aegean. Exhumation data is compiled from Wawrzenitz and Krohe (1998), Kounov et al. (2015, 2020), Dinter et al. (1995), Zattin et al. (2005, 2010), and Cavazza et al. (2009) 
The Eocene-Oligocene sequence north of Saros Bay has been deformed into a large, asymmetric, $\mathrm{N} 65^{\circ} \mathrm{E}$ trending, open anticline with an axis length of $20 \mathrm{~km}$ and a width of 9 $\mathrm{km}$. This Koruda $\breve{g}$ anticline has formed during the Late Oligocene-Early Miocene (28-17 Ma) shortening in a N25 ${ }^{\circ} \mathrm{W}$ direction.

A phase of Late Oligocene-Early Miocene (28 Ma to $17 \mathrm{Ma}$ ) shortening in the northern Aegean is indicated by the presence of Korudağ anticline, other large folds in the Thrace Basin, and other structures in the Balkans. This minor contractional phase occurs between two major extensional episodes and is probably related to changes in the subduction dynamics along the Hellenic trench.

Acknowledgements This study is the outcome of the thesis of the first author and supported by the TÜBİTAK project 116Y127, İTÜ BAP project TYL-2018-41712 and by TÜBA. We thank Andrew R.C. Kylander-Clark for zircon U-Pb dating, Cemre Ay for help during the fieldwork, Muzaffer Siyako, Ercan Özcan, Demir Altıner and Gerçek Saraç for discussions and information, and Mutlu Özkan for GIS data. Critical and positive comments by Nurettin Kaymakçı, Neven Georgiev and an anonymous reviewer considerably improved the manuscript.

Funding Open Access funding enabled and organized by Projekt DEAL.

Open Access This article is licensed under a Creative Commons Attribution 4.0 International License, which permits use, sharing, adaptation, distribution and reproduction in any medium or format, as long as you give appropriate credit to the original author(s) and the source, provide a link to the Creative Commons licence, and indicate if changes were made. The images or other third party material in this article are included in the article's Creative Commons licence, unless indicated otherwise in a credit line to the material. If material is not included in the article's Creative Commons licence and your intended use is not permitted by statutory regulation or exceeds the permitted use, you will need to obtain permission directly from the copyright holder. To view a copy of this licence, visit http://creativecommons.org/licenses/by/4.0/.

\section{References}

Armijo R, Meyer B, Hubert A, Barka A (1999) Westward propagation of the North Anatolian fault into the northern Aegean: timing and kinematics. Geology 27:267-270

Barka A (1992) The North Anatolian fault zone. Ann Tecton 6:164-195

Berggren WA, Kent DV, Swisher CC, Aubry MP (1995) A revised Cenozoic geochronology and chronostratigraphy. In: Berggren WA, Kent DV, Aubry MP, Hardenbol J (eds) Geochronology, time scales and global stratigraphic correlation. Society of Economic Paleontologists and Mineralogists (SEPM), Special Publication, vol 54, pp 129-212

Boyanov I, Goranov A (2001) Late Alpine (Palaeogene) superimposed depressions in parts of southeastern Bulgaria. Geol Balc 31:3-26

Brun JP, Sokoutis D (2018) Core complex segmentation in north Aegean, a dynamic view. Tectonics 37:1797-1830

Brun J-P, Faccenna C, Gueydan F, Sokoutis D, Philippon M, Kydonakis K, Gorini C (2016) The two-stage Aegean extension, from localized to distributed, a result of slab rollback acceleration. Can J Earth Sci 53:1142-1157
Burchfiel BC, Nakov R, Dumurdzanov N, Papanikolaou D, Tzankov T, Serafimovski T, King RW, Kotzev V, Todosov A, Nurce B (2008) Evolution and dynamics of the Cenozoic tectonics of the South Balkan extensional system. Geosphere 4:919-938

Caracciolo L, Critelli S, Cavazza W, Meinhold G, von Eynatten H, Manetti P (2015) The Rhodope Zone as a primary sediment source of the southern Thrace basin (NE Greece and NW Turkey): evidence from detrital heavy minerals and implications for central-eastern Mediterranean palaeogeography. Int J Earth Sci 104:815-832

Cavazza W, Okay AI, Zattin M (2009) Rapid early-middle Miocene exhumation of the Kazdağ Massif (western Anatolia). Int J Earth Sci 98:1935-1947

Cavazza W, Caracciolo L, Critelli S, Datri A, Zuffa GG (2013) Petrostratigraphic evolution of the Thrace Basin (Bulgaria, Greece, Turkey) within the context of Eocene-Oligocene post-collisional evolution of the Vardar-Izmir-Ankara suture zone. Geodin Acta 26:12-26

Dinter DA, Macfarlane A, Hames W, Isachsen C, Bowring S, Royden $\mathrm{L}$ (1995) U-Pb and 40Ar/39Ar geochronology of the Symvolon granodiorite: implications for the thermal and structural evolution of the Rhodope metamorphic core complex, northeastern Greece. Tectonics 14:886-908

Doust H, Arıkan Y (1974) The geology of the Thrace Basin. In: Proceedings 2nd petroleum congress of Turkey, Ankara, pp 119-136

Dumurdzanov N, Serafimovski T, Clark Burchfiel B (2005) Cenozoic tectonics of Macedonia and its relation to the South Balkan extensional regime. Geosphere 1:1-22

Georgiev N, Pleuger J, Froitzheim N, Sarov S, Jahn-Awe S, Nagel TJ (2010) Separate Eocene-Early Oligocene and Miocene stages of extension and core complex formation in the Western Rhodopes, Mesta Basin, and Pirin Mountains (Bulgaria). Tectonophysics 487:59-84

Gerdjikov I, Georgiev N (2006) The Maritsa fault system-a strike-slip zone along the northern margin of the Rhodopes. St Ivan Rilski Univ Min Geol Annu 49:33-39

Hetzel R, Ring U, Akal C, Troesch M (1995) Miocene NNE-directed extensional unroofing in the Menderes Massif, southwestern Turkey. J Geol Soc Lond 152:639-654

Innocenti F, Manetti P, Mazzuoli R, Pertusati P, Fytikas M, Kolios N (1994) Geology and geodynamic significance of the Island of Limnos, North Aegean Sea, Greece. N Jb Geol Palaont 11:661-691

Jolivet L, Brun JP (2010) Cenozoic geodynamic evolution of the Aegean. Int J Earth Sci 99:109-138

Jolivet L, Faccenna C, Huet B, Labrousse L, Le Pourhiet L, Lacombe $\mathrm{O}$, Lecomte E, Burov E, Denèle Y, Brun JP, Philippon M, Paul A, Salaün G, Karabulut H, Piromallo C, Monié P, Gueydan F, Okay AI, Oberhänsli R, Pourteau A, Augier R, Gadenne L, Driussi O (2013) Aegean tectonics: strain localisation, slab tearing and trench retreat. Tectonophysics 597-598:1-33

Karakaş Ç, Armijo R, Lacassin R, Suc J, Melinte-Dobrinescu MC (2018) Crustal strain in the Marmara pull-apart region associated with the propagation process of the North Anatolian Fault. Tectonics 37:1507-1523

Kaymakc1 N, Aldanmaz E, Langereis C, Spel TL, Gurer OF, Zanetti A (2007) Late Miocene transcurrent tectonics in NW Turkey: evidence from paleomagnetism and 40Ar-39Ar dating of alkaline volcanic rocks. Geol Mag 144:379-392

Kilias A, Falalakis G, Sfeikos A, Papadimitriou E, Vamvaka A, Gkarlaouni (2013) The Thrace basin in the Rhodope province of NE Greece-a tertiary supradetachment basin and its geodynamic implications. Tectonophysics 595-596:90-105

Knitter H (1979) Eine verbesserte methode zur gewinnung von mikrofosilien aus harten, nicht schlambaren kalken. Geologische Blätter Nord-Bayern 29:182-186 
Kopp KO, Pavoni N, Schindler C (1969) Geologie Thrakiens IV: Das Ergene Becken. Beihefte Geol Jahrbuch 76:1-136

Kounov A, Wüthrich E, Seward D, Burg JP, Stockli D (2015) Lowtemperature constraints on the Cenozoic thermal evolution of the Southern Rhodope Core Complex (Northern Greece). Int J Earth Sci 104:1337-1352

Kounov A, Wüthrich E, Seward D, Burg JP, Stockli D (2020) Cenozoic thermal evolution of the Central Rhodope Metamorphic Complex (Southern Bulgaria). Int J Earth Sci 109:1589-1611

Kylander-Clark ARC, Hacker BR, Cottle JM (2013) Laser-ablation split-stream ICP petrochronology. Chem Geol 345:99-112

Le Pichon X, Angelier J (1979) The Hellenic arc and trench system: a key to the neotectonics evolution of the Eastern Mediterranean area. Tectonophysics 60:1-42

Lebküchner RF (1974) Beitrag zur Kenntnis des Geologie des Oligozäns von Mittel Thrakien (Türkei). Bull Miner Res Explor Inst Turkey 83:1-30

Less G, Özcan E, Okay AI (2011) Stratigraphy and larger foraminifera of the middle Eocene to lower Oligocene shallow-marine units in the northern and eastern parts of the Thrace Basin, NW Turkey. Turk J Earth Sci 20:793-845

Okay AI, Satir M (2000) Coeval plutonism and metamorphism in a latest Oligocene metamorphic core complex in northwest Turkey. Geol Mag 137:495-516

Okay AI, Kaşlilar-Özcan A, Imren C, Boztepe-Güney A, Demirbağ E, Kuşçu I (2000) Active faults and evolving strike-slip basins in the Marmara Sea, northwest Turkey: a multichannel seismic reflection study. Tectonophysics 321:189-218

Okay AI, Tüysüz O, Kaya Ş (2004) From transpression to transtension: changes in morphology and structure around a bend on the North Anatolian Fault in the Marmara region. Tectonophysics 391:259-282

Okay AI, Özcan E, Cavazza W, Okay N, Less G (2010) Basement types, lower Eocene series, upper Eocene olistostromes and the initiation of the southern Thrace Basin, NW Turkey. Turk J Earth Sci 19:1-25

Okay AI, Özcan E, Hakyemez A, Siyako M, Sunal G, Kylander-Clarck A (2019) The Thrace Basin and the Black Sea: the Eocene-Oligocene marine connection. Geol Mag 156:39-61

Okay AI, Zattin M, Özcan E, Sunal G (2020) Uplift of Anatolia. Turk J Earth Sci 29:696-713

Özcan E, Less G, Okay AI, Báldi-Beke M, Kollányi K, Ömer Yilmaz I (2010) Stratigraphy and larger foraminifera of the Eocene shallowmarine and olistostromal units of the southern part of the Thrace Basin, NW Turkey. Turk J Earth Sci 19:27-77

Pearson PN, Olsson RK, Huber BT, Hemleben C, Berggren WA (2006) Atlas of Eocene planktonic foraminifera. Cushman Foundation for Foraminiferal Research, Fredericksburg, USA, Special Publication no. 41

Perincek D (1991) Possible strand of the North Anatolian Fault in the Thrace Basin, Turkey-an interpretation. Am Assoc Pet Geol Bull 75:241-257

Pleuger J, Georgiev N, Jahn-Awe S, Froitzheim N, Valkanov N (2011) Kinematics of Palaeogene low-angle extensional faults and basin formation along the eastern border of the Central Rhodopes (Bulgaria). Z dt Ges Geowiss 162:171-192

Reilinger R, McClusky S, Paradissis D, Ergintav S, Vernant P (2010) Geodetic constraints on the tectonic evolution of the Aegean region and strain accumulation along the Hellenic subduction zone. Tectonophysics 488:22-23
Şafak Ü, Güldürek M (2016) The ostracoda assemblage of the EoceneOligocene transition in northwestern Thrace: Kırklareli-Edirne area (northwestern Turkey). J Asian Earth Sci 117:62-85

Şen Ş, Yillar S (2009) The Korudağ anticlinorium in the south Thrace Basin, northwest Turkey: a super giant petroleum trap complex? Am Assoc Petrol Geol Bull 93:357-377

Şengör AMC (1979) The North Anatolian transform fault: its age, offset and tectonic significance. J. Geol Soc Lond 136:269-282

Şentürk K, Sümengen M, Terlemez İ, Karaköse C (1998) 1:100 000 scale geological maps and explanatory notes, Turkey, ÇanakkaleD3 (G17) Sheet, No. 63 Publication of the General Directorate of Mineral Research and Exploration (MTA), Ankara

Siyako M, Huvaz O (2007) Eocene stratigraphic evolution of the Thrace Basin, Turkey. Sedim Geol 198:75-91

Sümengen M, Terlemez I (1991) Stratigraphy of Eocene sediments in the southwest Thrace. Bull Miner Res Explor Inst Turk 113:15-29

Suppe J, Medvedeff DA (1990) Geometry and kinematics of faultpropagation folding. Eclogae Geol Helv 83:409-454

Ternek Z (1949) Geological study of the region of Keşan-Korudağ. Publication of the Institute of Mineral Research and Exploration (MTA), Ankara, D12

Topuz G, Okay AI, Altherr R, Satir M, Schwarz WH (2008) Late Cretaceous blueschist facies metamorphism in southern Thrace (Turkey) and its geodynamic implications. J Metamorph Geol 26:895-913

Turgut S, Türkaslan M, Perinçek D (1991) Evolution of the Thrace sedimentary basin and its hydrocarbon prospectivity. In: Spencer AM (ed) Generation, accumulation and production of Europe's hydrocarbons. Special Publication of European Association of Petroleum Geoscientists, vol 1, pp 415-437

Türkecan A, Yurtsever A (2002) Geological Map of Turkey, İstanbul sheet, Scal: 1/500 000. Publ General Directorate of Mineral Research and Exploration (MTA), Ankara

Tüysüz O, Barka A, Yiğitbaş E (1998) Geology of the Saros graben and its implications for the evolution of the North Anatolian fault in the Ganos-Saros region, northwest Turkey. Tectonophysics 292:105-126

Ünay E, de Bruijn H (1984) On some rodent assemblages from both sides of the Dardanelles, Turkey. Newslett STRAT 13:119-132

Wawrzenitz N, Krohe A (1998) Exhumation and doming of the Thasos metamorphic core complex (S Rhodope, Greece): structural and geochronological constraints. Tectonophysics 285:301-332

Yaltırak C, Sakınç M, Oktay FY (2000) Discussion "Westward propagation of North Anatolian fault into the northern Aegean: timing and kinematics". Geology 28:187-188

Yaltırak C, Sakınç M, Özkar-Öngen İ (2002) Çeltik Limestone. Abstracts of the Workshop on the Lithostratigraphy of the Thrace Basin, Ankara, p 8

Yücel AO, Özcan E, Erbil Ü (2020) Latest Priabonian larger benthic foraminiferal assemblages at the demise of the Soğucak carbonate platform (Thrace Basin and Black Sea shelf, NW Turkey): implications for the shallow marine biostratigraphy. Turk J Earth Sci 29:85-114

Zattin M, Okay AI, Cavazza W (2005) Fission-track evidence for late Oligocene and mid-Miocene activity along the North Anatolian Fault in south-western Thrace. Terra Nova 17:95-101

Zattin M, Cavazza W, Okay AI, Federici I, Fellin MG, Pignalosa A, Reiners P (2010) A precursor of the North Anatolian Fault in the Marmara Sea region. J Asian Earth Sci 39:97-108 